Voix et Images

volxetimages

\title{
Cinéma : Robin(e) des bois au pays du Québec
}

\section{Gilles Thérien}

Volume 3, numéro 2, décembre 1977

Victor-Lévy Beaulieu

URI : https://id.erudit.org/iderudit/200114ar

DOI : https://doi.org/10.7202/200114ar

Aller au sommaire du numéro

\section{Éditeur(s)}

Les Presses de l'Université du Québec

\section{ISSN}

0318-9201 (imprimé)

1705-933X (numérique)

Découvrir la revue

\section{Citer cet article}

Thérien, G. (1977). Cinéma : Robin(e) des bois au pays du Québec. Voix et Images, 3(2), 334-335. https://doi.org/10.7202/200114ar d'utilisation que vous pouvez consulter en ligne.

https://apropos.erudit.org/fr/usagers/politique-dutilisation/ 


\section{Cinéma \\ Robin(e) des bois au pays du Québec}

En juillet 1976, le ministère québécois des Affaires sociales publiait un volumineux rapport intitulé Étude sur les effets médicaux et toxicologiques du mercure organique dans le Nord-Ouest québécois. On y lit entre autres: "Toute concentration de ce métal (mercure) dans les tissus, si faible soit-elle, devient donc une agression contre les systèmes enzymatiques responsables de l'homéostatisme métabolique. Selon la susceptibilité individuelle des sujets (déterminée par plusieurs facteurs dont l'hérédité et l'état nutritionnel), ce mercure deviendra cytotoxique, c'est-à-dire qu'il nuira au fonctionnement de la cellule, jusqu'au point de causer sa mort. Tout apport de mercure chez l'homme est donc nuisible à la santé." (p. 170-171). II est possible que Jean Salvy et Jean-Claude Lord aient lu ce rapport avant de concocter le scénario du film de Lord, Panique.

En octobre 1977, le ministre de l'Environnement, Marcel Léger, invitait l'Assemblée nationale à un visionnement du film. Les honorables en seront quittes pour leur déplacement. Le film est plus facile à digérer mentalement qu'un rapport d'études, d'autant que ce dernier ne fait appel ni à la panique ni au miracle. Ils verront ce qu'ils savent déjà: que les politiciens sont corrompus, que l'argent mène le monde, que les Américains sont encore plus méchants que nous, que Robin(e) des bois est là, prêt(e) à nous sauver.

Un critique enthousiaste et certainement distrait a parlé de JeanClaude Lord en le disant le Cayatte de nos cinéastes. II est vrai que JeanNoël Tremblay a été notre Malraux, que René Lévesque est un mélange de Mao, Churchill et de Gaulle. L'inflation a gagné le langage. Les épithètes sont à la baisse. Lord est un raccoleur, un maître du simplisme. Panique est un tissu d'invraisemblances à propos d'un problème réel, urgent et très grave. La fiction corrompt tout. Sa pollution fictive est à mi-chemin entre la maladie de Minamata et le virus d'une grippe intestinale. Le film s'applique à montrer comment les pauvres bons et les mauvais riches passent ensemble un petit quart d'heure. La moralité sera sauvée quand la naïve 
publiciste (ça existe?) se rend compte soudainement qu'on lui a menti. Elle aura, du coup, oublié son métier de mensonge, son rôle de maîtresse du ministre de l'Industrie puis du président de la toute puissante JIT. Pure comme l'eau de source, elle emploie son temps précieux (et le nôtre) à expliquer leurs malheurs aux malheureux... au risque de se voir emprisonnée. Elle sauvera la population du Québec, Robin(e) des bois à la tête d'un commando digne de la légende.

Ce genre de film pose profondément le problème de l'honnêteté du cinéma et du cinéaste. Ce film ne dénonce pas, il occulte. Ce qu'il dit, nous le savions déjà; ce qu'il cache, nous risquons de ne jamais le savoir. L'empoisonnement de notre environnement, les conséquences neurologiques, la transmission génétique, l'exigence d'un total changement d'attitudes chez tous les individus, voilà des choses qui auront été à peine effleurées, transformées en séquences de film d'horreur ou en pseudo-réflexion politique. Et puis, le poison est dans l'eau... alors que tous les jours, nous mangeons des viandes et des poissons possiblement porteurs de mercure et que déjà les plus atteints, et ils sont nombreux, sont les Indiens, nos frères inconnus et minoritaires. Le film exalte le sensationalisme "à la petite semaine", avec des centaines de figurants, d'ambulances, de policiers, de politiciens. II ignore volontairement toutes les explications un peu importantes, utiles à notre compréhension. C'est vrai qu'il ne faut pas fatiguer le pauvre spectateur qui paie $\$ 3.75$ pour croire qu'il n'est pas responsable de la pollution, qu'il n'en est que la victime et que la seule pollution mortelle se boive. Lord, logiquement, aurait dû terminer son film avec une annonce de bière dont les compagnies sont aussi, de façon générale, des multinationales. 